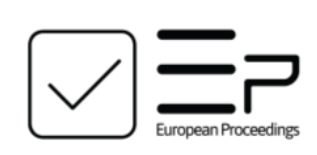

European Proceedings of

International Conference on Education \&

Educational Psychology

EPICEEPSY

www.europeanproceedings.com

e-ISSN: 2672-8141

DOI: $10.15405 /$ epiceepsy.21101.3

ICEEPSY 2021

$12^{\text {th }}$ International Conference on Education \& Educational Psychology

\title{
TRENDS IN THE USE OF NON-FORMAL ADULT EDUCATION SUPPLY
}

\author{
Jan Kalenda (a)*, Ilona Kočvarová (b), Jitka Vaculíková (c) \\ *Corresponding author \\ (a) Faculty of Humanities, Research Centre of FHS, Tomas Bata University in Zlín, Zlín, Czech Republic, \\ kalenda@utb.cz \\ (b) Faculty of Humanities, Research Centre of FHS, Tomas Bata University in Zlín, Zlín, Czech Republic, \\ kocvarova@utb.cz \\ (c) Faculty of Humanities, Research Centre of FHS, Tomas Bata University in Zlín, Zlín, Czech Republic, \\ vaculikova@utb.cz
}

\begin{abstract}
Although non-formal adult education (NFE) is one of the most widespread forms of lifelong learning today, we still have not enough knowledge about the structure of its supply side and the factors that influence the use of different types of NFE. The paper, therefore, deals with the transformation of the use of NFE supply for adults in the Czech Republic in 2011-2016. The aim of the paper is to (1) show the development dynamics of the use of NFE offer, both in terms of job-oriented and non-job-oriented education and training. Following this, we intend to (2) determine the structure of adults who use different types of NFE. This will allow us to map the groups of adults who benefit most from (a) courses, (b) workshops, (c) private tuition, and (d) guided on-the-job training. We use a secondary analysis of the data from the Adult Education Survey from $2011(\mathrm{~N}=3,263)$ and $2016(\mathrm{~N}=4,840)$ and compare them to meet these goals. The results of both surveys are processed using descriptive and cluster analysis. Based on the data analysis, we demonstrate a significant increase in guided on-the-job training as the primary type of NFE used by adults across all socio-demographic groups. This result suggests a significant neoliberealization and instrumentalization of the NFE offer, which displaces non-job-oriented education and longer-term and more formalized models of education and individualized adult learning.
\end{abstract}

2672-8141 C 2021 Published by European Publisher.

Keywords: Adult education and training, supply side, types of non-formal education, and participation 


\section{Introduction}

The period after 2010 was one of the most dynamic in terms of the development of non-formal education of adults (NFE). Specifically, it has intensified processes such as globalisation, deindustrialisation, and the subsequent flexibilisation and precarization of work, which resulted in an increased demand for NFE (e.g., Desjardins, 2020a; Desjardins \& Ioannidou, 2020; Kalenda \& Kočvarová, 2020). At the same time, the NFE supply itself began to change more profoundly. It has seen new technological innovations and types of organisation of learning activities, which, on the one hand, increase its flexibility and accessibility, but on the other hand, lead to higher demands on the digital skills of learners (Hämäläinen et al., 2015; Merriam \& Baumgartner, 2020; Nygren et al., 2019).

Based on that, the study deals with the trends in the development of use NFE supply after 2010. First, it focuses on determining the critical trends in NFE according to the types of organization of learning activities (e.g., courses, private lessons, guided on-the-job training). Second, it focuses on the change of participants in these activities, determining the factors influencing the involvement of adults in different types of NFE.

\subsection{NFE}

We define NFE following the existing international documents (CEDEFOP, 2008, Eurostat, 2016a, 2016b; UNESCO, 2020) as learning activities outside the formal educational system. It involves structured activities that usually do not result in official certification, according to ISCED (2011). This type of learning includes all organized and planned development activities, such as courses, workshops, and private lessons or training in the workplace. NFE also includes both job-oriented (vocational) as well as non-job-oriented learning.

As to the NFE offer, its overall scope is crucial, as it is the most widespread form of organized lifelong learning for adults, with 30 to $50 \%$ of adults in many Central and Western European countries (Desjardins, 2017, 2020a; Desjardins et al., 2016; Rubenson, 2018). Its importance lies in the fact that it is an important tool for upskilling and reskilling in the field of work, where it complements or replaces vocational education and training and the fact that it has several noneconomic functions. In this regard, it increases adults' civic engagement (Grotlüschen et al., 2019) and improves their quality of life and health (Iňiguez-Berrozpe et al., 2020). It also contributes to community development (Kalenda \& Smékalová, 2015) and active population ageing (Desjardins, 2020b).

\subsection{Types of NFE}

As regards its organisation, according to ISCED (2011) and the Classification of learning activities of the European Commission (Eurostat, 2016a, 2016b), NFE is divided into:

(1) Courses that are typically subject-oriented and are taught by one or more people specialised in a specific field. They may occur in one or more settings/environments, including the online/elearning environment. They include learning organised for a group of adults in a classroom or on a digital platform. It is built around a teacher/tutor/instructor passing on knowledge to provide instruction and educate. 
(2) Workshops (combined theoretical-practical courses) cover all educational activities that combine classroom-based instruction (theoretical) with practice in real or simulated situations. It includes vocational apprenticeships, except those covered by formal educational institutions. Combined theoretical-practical courses also include learning activities that mix classroom instruction with guided-on-the-job training and practice.

(3) Private tuition (private lessons). This type of NFE represents a planned series of learning experiences offered by experts or others who act as experts, selected to deepen knowledge or skills, to learn more intensively, usually undertaken by only one or very few learners. Typically, the tutor is also the education provider.

(4) Guided-on-the-job training. This organized learning activity is characterised by planned periods of training, instruction or practical experience, using normal tools of work, either at the immediate place of work or in a work situation. On-the-job training is usually organised by the employer to make it easier for workers. It may include general training about the company as well as specific job-related instructions.

\subsection{Trends in NFE}

The development of NFE in the last decade is characterized by three trends that may affect the supply of individual learning activities:

(1) The development of flexible and agile forms of learning such as e-learning, micro-learning, etc., which lead to a lower level of long-term planning, structuring and organization of NFE, transferring emphasis to learning within the social environment (community of inquiry/learning) and a higher degree of individualization (Kearns, 2015; Messmann et al., 2018; Merriam \& Baumgartner, 2020). As a result, we may expect a decrease in the demand for traditional forms of learning activities, such as courses and workshops, which are not suitable tools for agile learning and flexible skills development (Lancaster, 2020), both for the job-oriented and non-joboriented forms of NFE.

(2) An increase in job-oriented training. According to a number of researchers (Desjardins et al., 2016; Kalenda \& Kočvarová, 2020; Rubenson, 2018), in the case of NFE, we may observe both an increase in the share of education and training focused on work skills and an increase in the proportion of learning activities paid for by employers. Due to the NFE's inclination towards the world of work, it can therefore be expected that the share of guided on-the-job training, which will form the central part of all NFE training activities, will increase. In other words, there will be a homogenization of NFE in terms of this learning activity.

(3) An overall increase in NFE participation in most countries (Desjardins, 2017, 2020a; Rubenson, 2018) should reduce inequalities in participation in different types of NFE among different social groups. As a result, traditional inequalities such as gender, age, and education should not play a significant role in engaging in different types of NFE. These are forms of private tuition which may have the highest costs in terms of learners and which (economic) inequalities may intervene most strongly. 


\section{Problem Statement}

Although NFE is one of the most widespread forms of lifelong learning, which underwent dramatic changes in the last decade, we still have only basic knowledge of the changing offer of its various types and factors that influence adult involvement in them. If NFE is researched, the participation of individuals in different educational activities is usually not considered (e.g., Boeren, 2016, 2017; Lee, 2017; Lee \& Desjardins, 2019; Merriam \& Baumgartner, 2020; Rubenson, 2018). In representative surveys from the Czech Republic, participation in various NFE types has not yet been addressed (e.g. Kalenda 2015; Kalenda et al., 2020; Vaculíková et al., 2020).

\section{Research Questions}

Regarding the identified research problems, the study focuses on answering three interconnected research questions:

(1) $\mathrm{RQ}_{1}$ : What was the development of the use of various types of NFE in CZ after 2010?

(2) $\mathrm{RQ}_{2}$ : How did the development of the use of different types of NFE differ between joboriented and non-job-oriented training?

(3) $\mathrm{RQ}_{3}$ : What kind of groups of participants can be identified? What are their key characteristics and how did they change between 2011 and 2016 ?

\section{Purpose of the Study}

Following these questions, the study aims to map out: (1) The development of the use of different types of NFE in the field of job-oriented and non-job-oriented training between 2011 and 2016 (see, RQ and $\mathrm{RQ}_{2}$ ); (2) the groups of participants in particular types of NFE between 2011 and 2016: (a) courses, (b) workshops, (c) private tuition, (d) guided on-the-job training, and describe their basic sociodemographic features (see, $\left.\mathrm{RQ}_{3}\right)$.

\section{Research Methods}

We use a secondary analysis of the data from the Adult Education Survey (AES) from 2011 $(\mathrm{N}=10,253)$ and $2016(\mathrm{~N}=12,468)$ and compare them to meet these goals. Only NFE participants were included in the analysis, who also stated whether their participation was primarily job-related or personalrelated, namely, $n=3263$ (AES 2011) and $n=4840$ (AES 2016). The results of both surveys are processed using descriptive and cluster analysis (K-means cluster) focused on the change of crucial variables, i.e., the forms of NFE offered and microsocial factors, including motivation for education. As part of the analysis, weights were applied to ensure the representativeness of both samples for the Czech Republic.

\section{Findings}

The results of the development of participation in individual types of NFE in 2011 and 2016 are summarized in Table 1. The first part of the results is devoted to the research questions RQ1 and RQ2. 
Respondents could choose from four types of NFE offered: courses, workshops and seminars, private tuition, guided-on-the-job training. In this case, they could choose more than one option at a time (not just one). In 2011, 706 (22\%) people chose more than one option, and in 2016 it was 940 (19\%). Thus, the table includes a larger number of responses than the number of respondents included in the analysis. Specifically, there are 4109 responses in 2011 and 5954 responses in 2016. Both values serve as a basis (100\%) for calculating the percentages in the table.

Table 1. Participation in different types of NFE activities in 2011 and 2016

\begin{tabular}{ccccc}
\hline Type of NFE activity & Courses & Workshops & Private tuition & $\begin{array}{c}\text { Organised on-the } \\
\text { job-training }\end{array}$ \\
\hline $\begin{array}{c}\text { Job-oriented-training 2011 } \\
\text { Non-job-oriented-training } \\
2011\end{array}$ & $29 \%$ & $15 \%$ & $4 \%$ & $28 \%$ \\
Total 2011 & $13 \%$ & $4 \%$ & $5 \%$ & $2 \%$ \\
\hline $\begin{array}{c}\text { Job-oriented-training 2016 } \\
\text { Non-job-oriented-training }\end{array}$ & $42 \%$ & $19 \%$ & $10 \%$ & $29 \%$ \\
\hline Total 2016 & $10 \%$ & $9 \%$ & $4 \%$ & $50 \%$ \\
\hline Difference 2011-2016 (p.p.) & -18 & $4 \%$ & $10 \%$ & $2 \%$ \\
\hline
\end{tabular}

The table shows that all four types of NFE offered in 2011 and 2016 were more job-oriented than personal-related. The only exceptions are private lessons, where non-job-related reasons slightly prevail. In terms of individual types of educational offer, courses strongly prevailed (42\%) in 2011. Contrary, in 2016, there was less use of courses (-18 p.p.), and we see a strong inclination to use guided-on-the-job training (a total of $52 \%,+23$ p.p.). The increase is only visible among people who declare its job-oriented purpose. In the case of workshops, we see a slight decrease ( -6 p.p.). In the case of private tuition, the situation does not change.

For answering the research question RQ3, cluster analysis (K-means cluster) was applied based on preferences for one of the four types of NFE supply. As part of the cluster analysis, we generated solutions for two to five clusters for both years. We assessed all solutions in detail and finally decided on three clusters in both waves of AES. With a higher number of clusters, the solution broke down into small subgroups making up less than $10 \%$ of the research population. It was essential for us to identify the basic types. The results are presented in Table 2.

In both waves of AES, Cluster I. (mostly on-the-job training participants) is saturated with participants of guided on-the-job training (100\%) in combination with other types of activities not exceeding $25 \%$ in 2011 and $13 \%$ in 2016. In 2011 it contains $37 \%$ respondents, in 2016 it is $64 \%$ (+ 27 p.p.). After five years, we can see that it is much bigger and much more concentrated on simply guided onthe-job training with fewer combinations with other types of activities. 
Table 2. Clusters of participants in four types of NFE activities in $2011(\mathrm{n}=3263)$ and $2016(4840)$

\begin{tabular}{lcccccc}
\hline & \multicolumn{3}{c}{ Clusters for 2011 } & \multicolumn{3}{c}{ Clusters for 2016 } \\
\cline { 2 - 7 } & I. & II. & III. & I. & II. & III. \\
& $(\mathrm{n}=1211 ;$ & $(\mathrm{n}=639 ;$ & $(\mathrm{n}=1413 ;$ & $(\mathrm{n}=3088 ;$ & $(\mathrm{n}=488 ;$ & $(\mathrm{n}=1265 ;$ \\
& $37 \%)$ & $20 \%)$ & $43 \%)$ & $64 \%)$ & $10 \%)$ & $26 \%)$ \\
\hline Courses & $25 \%$ & $34 \%$ & $85 \%$ & $13 \%$ & $20 \%$ & $76 \%$ \\
Workshops & $12 \%$ & $100 \%$ & $0 \%$ & $9 \%$ & $100 \%$ & $3 \%$ \\
On-the-job training* & $100 \%$ & $0 \%$ & $0 \%$ & $100 \%$ & $0 \%$ & $3 \%$ \\
Private tuition & $6 \%$ & $9 \%$ & $19 \%$ & $4 \%$ & $7 \%$ & $35 \%$ \\
\hline
\end{tabular}

Cluster II. (mostly workshop participants) predominantly consists of adults oriented to workshops. It is the smallest one in both years, and it is even smaller in 2016 (10\%) than in $2011(20 \%)$. Here, the combinations with other kinds of activities are also getting weaker.

Cluster III. (mostly course participants) is deeply but not fully connected with courses. In 2011 it was the biggest one (43\%), but in 2016 it is much smaller ( $26 \%$; -17 p.p.). On the contrary to other clusters, there is no lower rate of combination with other types of offers. Moreover, combinations are more frequent, especially with private tuition. It is worth mentioning that there is no cluster strongly aimed at private lessons. These are used by adult learners minimally, as already presented in Table 1.

Table 3. Basic socio-demographic characteristics of clusters in $2011(\mathrm{n}=3263)$ and $2016(4840)$

\begin{tabular}{|c|c|c|c|c|c|c|}
\hline & \multicolumn{3}{|c|}{ Clusters for 2011} & \multicolumn{3}{|c|}{ Clusters for 2016} \\
\hline & I. & II. & III. & I. & II. & III. \\
\hline Male & $58 \%$ & $42 \%$ & $47 \%$ & $61 \%$ & $35 \%$ & $39 \%$ \\
\hline Female & $42 \%$ & $58 \%$ & $53 \%$ & $39 \%$ & $65 \%$ & $61 \%$ \\
\hline Age $18-29$ & $22 \%$ & $16 \%$ & $28 \%$ & $15 \%$ & $21 \%$ & $28 \%$ \\
\hline Age $30-50$ & $59 \%$ & $58 \%$ & $52 \%$ & $61 \%$ & $49 \%$ & $51 \%$ \\
\hline Age $51-69$ & $19 \%$ & $27 \%$ & $20 \%$ & $24 \%$ & $30 \%$ & $21 \%$ \\
\hline ISCED 0-2 & $3 \%$ & $1 \%$ & $8 \%$ & $2 \%$ & $1 \%$ & $8 \%$ \\
\hline ISCED 3c & $34 \%$ & $10 \%$ & $22 \%$ & $32 \%$ & $17 \%$ & $18 \%$ \\
\hline ISCED $3 a b$ & $43 \%$ & $42 \%$ & $45 \%$ & $40 \%$ & $42 \%$ & $42 \%$ \\
\hline ISCED 5-6 & $20 \%$ & $47 \%$ & $25 \%$ & $26 \%$ & $40 \%$ & $33 \%$ \\
\hline Job-related participation & $94 \%$ & $80 \%$ & $59 \%$ & $96 \%$ & $62 \%$ & $47 \%$ \\
\hline Non-job-related participation & $6 \%$ & $20 \%$ & $41 \%$ & $4 \%$ & $38 \%$ & $53 \%$ \\
\hline Full time job & $96 \%$ & $84 \%$ & $69 \%$ & $95 \%$ & $69 \%$ & $61 \%$ \\
\hline Part time job & $2 \%$ & $3 \%$ & $2 \%$ & $3 \%$ & $3 \%$ & $5 \%$ \\
\hline Unemployed & $1 \%$ & $1 \%$ & $6 \%$ & $1 \%$ & $1 \%$ & $4 \%$ \\
\hline Student / unpaid work & $0 \%$ & $4 \%$ & $14 \%$ & $0 \%$ & $8 \%$ & $15 \%$ \\
\hline Retired & $0 \%$ & $5 \%$ & $5 \%$ & $1 \%$ & $11 \%$ & $7 \%$ \\
\hline Disabled / inactive & $0 \%$ & $0 \%$ & $1 \%$ & $0 \%$ & $1 \%$ & $2 \%$ \\
\hline Fulfilling domestic tasks & $0 \%$ & $4 \%$ & $4 \%$ & $1 \%$ & $6 \%$ & $7 \%$ \\
\hline
\end{tabular}

Data source: Adult education survey $(2011,2016)$. Note. Own calculation. ISCED = ISCED = International Standard Classification of Education.

Cluster analysis was followed by basic descriptive characteristics of the final cluster solutions for 2011 and 2016, also included in Table 3. Cluster I increased the most in 2016, but its socio-demographic composition is almost identical to 2011. In contrast to that, Cluster II got smaller. At the same time, the share of persons participating in the NFE for job-related purposes (-18 p.p.) and persons working full time 
(-15 p.p.) decreased. Cluster III was also reduced. As in Cluster II, the share of people participating in the NFE for job-related purposes (-12 p.p.) and full-time employees (-8 p.p.) decreased in this cluster of adult learners.

\section{Conclusion}

The first of the two main aims of this paper was to analyse the development of different types of NFE between 2011 and 2016. Importantly, we found that the decline of participation in traditional types of organised learning - i.e., courses is typical for this phenomenon. The number of participants in them shattered to almost half during the investigated period. This empirical finding is in line with the current literature (e.g., Kearns, 2015; Lancaster, 2020; Messmann et al., 2018; Merriam \& Baumgartner, 2020), emphasising a higher demand for more flexible, experience-based and agile forms of organised learning. The same tendencies, but to a lesser degree, are also common for workshops, while private tuition did not change.

Another key identified trend is a rapid increase in the involvement of adults in organised on-the-job training, which almost doubles its size. According to some scholars (Desjardins, 2017; Desjardins \& Ioannidou, 2020; Rubenson, 2018), this result is compatible with an increased supply of job-related training characterised the previous decade. In the case of participation in NFE, it results not only in higher participation for work-related reasons and employer-supported training but also in higher utilisation of guided on-the-job training as a primary organisational type of NFE. On the one hand, it leads to the homogenisation of different forms of NFE towards one type. On the other hand, it makes NFE more economically and labour market centred than before. In other words, the results confirm neoliberal tendencies inside adult education (Milana et al., 2016) and its instrumentalisation, where learning practice increasingly depends on the private sector.

During the following second aim, analysis and depiction of groups of participants in different types of NFE, we identified three crucial social groups:

(1) Cluster I. (mostly on-the-job training participants). These are adults that dominantly learn for job-related reasons and are highly active in the labour market. Common features of the persons in this cluster are a higher proportion of males over females, adults between age 30 to 50 years, and the high occurrence of individuals with secondary education (ISCED 3) that form two-thirds of this group.

(2) Cluster II. (mostly workshop participants). The second cluster has a lower orientation to training dedicated to work-related skills. Furthermore, it has a higher proportion of older adults, many times retired persons. In addition, the tertiary level of education (ISCED 5-6) is typical for almost half of the members of this group. Finally, females are more frequent participants of this type of NFE than males.

(3) Cluster III. (mostly course participants). The participants of the courses gained their knowledge and skills for non-job-related reasons with higher occurrence than in previous types of NFE. Based on that, courses are the primary type of non-work-related education in our sample. Compared to other clusters, this one has a higher proportion of adults with just primary or low secondary education (ISCED 0-2 and ISCED 3c). Almost one-third of its members are low- 
educated. Moreover, females have a slightly higher representation in this group. Despite the involvement of other socioeconomic groups, courses are frequently used by students and adults fulfilling domestic tasks.

Interestingly, for this typology, it is essential that it has not changed too much since 2011 in its internal structure (i.e., the composition of the adults forming different participant groups) but in the size of the particular clusters. The cluster of participants learning through guided on-the-job training almost doubled its size, while the other two dwindled to half.

These findings confirm the homogenisation tendencies related to the development of different types of NFE elaborated above. The pattern found here corresponds to increased employer-sponsored and joboriented education (Desjardins, 2020a; Rubenson, 2018).

Our results also support thesis about existence of deep inequality inside participation in NFE (Boeren, 2016, 2017; Boyadjieva \& Ilieva-Trichkova, 2017, 2018; Desjardins et al., 2006; Lee, 2017; Lee \& Desjardins, 2019). Notably, the results reveal that inequalities exist not just in overall participation or number of training hours but also according to involvement in different types of NFE.

Although high-educated adults, actively involved in the labour market with full-time job contracts, are more frequent participants of workshops, low-educated people outside the labour market and with timerestricted job contracts participate more in courses. Similar to Busemeyer's (2015) work, the present study shows that adults at higher social risk also participate less in work-related NFE, mainly guided on-the-job training. This situation is not just typical for low-educated adults, unemployed, or elderly but also for females. In this regard, the same conclusions were drawn by several scholars (Dämmrich et al., 2015; Vaculíková et al., 2020), who reported higher support to males from employers.

\subsection{Study Limitations}

These results need to be interpreted with caution because they are based on the data from only one country - the Czech Republic. Its adult education system is characterised by a high level of skill mismatch (Hamplová \& Simonová, 2014), an orientation towards job-oriented learning (Kalenda \& Kočvarová, 2020) as well as high inequality in NFE according to integration into the labour market and educational attainment (Kalenda et al., 2020). For these reasons, our findings might not represent trends in the use of different types of NFE and the structure of their participants. As a consequence, this study failed to account for the international comparative dimension. The second downside of the used methodology lies in the secondary nature of our data sources (AES 2011 and 2016), enabling us to analyse only data from the first half of the previous decade. Due to this limitation, questions about the most recent trends affecting the world pandemic situation remain unanswered.

Even though this article provides a springboard for understanding trends in the use of different types of NFE among adults, more studies are needed to be done in this area. They should consider not only additional features of organized learning (e.g., online/offline organization platforms, involvement of tutors, or overall quality or length of learning), but also international comparative dimension, both in a spatial and temporal sense. 


\section{Acknowledgments}

This article was researched and written with the financial support of the Czech Science Foundation through the project Blind Spots of Non-formal Education in the Czech Republic: Nonparticipants and their Social Worlds, GA_19-00987S.

\section{References}

Boeren, E. (2016). Lifelong Learning Participation in a Changing Policy Context. An Interdisciplinary Theory. Palgrave Macmillan. https://doi.org/10.1057/9781137441836

Boeren, E. (2017). Understanding adult lifelong learning participation as a layered problem. Studies in Continuing Education, 39(2), 161-175. https://doi.org/10.1080/0158037X.2017.1310096

Boyadjieva, P., \& Ilieva-Trichkova, P. (2017). Between Inclusion and Fairness: Social Justice Perspective to Participation. Adult Education Quarterly, 67(2), 97-117. https://doi.org/10.1177/0741713616685398

Boyadjieva, P., \& Ilieva-Trichkova, P. (2018). Lifelong Learning as an Emancipation Process: A Capability Approach. In M. Milana et al. (Eds.), The Palgrave International Handbook on Adult and Lifelong Education and Learning (pp. 267-288). Palgrave Macmillan. https://doi.org/10.1057/978-1-13755783-4 15

Busemeyer, M. R. (2015). Skills and Inequality. Partisan politics and the political economy of education reforms in western welfare states. Cambridge University Press. https://doi.org/10.1017/CBO9781107477650

CEDEFOP (2008). Terminology of European education and training policy-a selection of 100 key terms CEDEFOP. Office for Official Publications of the European Communities.

Dämmrich, J., Kosyakova, Y., \& Blossfeld, H.-P. (2015). Gender and job-related non-formal training: A comparison of 20 countries. International Journal of Comparative Sociology, 56(6), 433-459. https://doi.org/10.1177/0020715215626769

Desjardins, R. (2017). Political Economy of Adult Learning Systems. Comparative Study of Strategies, Policies, and Constraints. Bloomsbury. https://doi.org/10.5040/9781474273671

Desjardins, P. (2020a). PIAAC Thematic Report on Adult Learning. OECD Education Working Paper No. 223. OECD.

Desjardins, R. (2020b). Acquiring Higher Levels of Education as an Adult Learner: Implications for Active Ageing. In M. Slowey, H. Schuetze, \& T. Zubrzycki (Eds.), Inequality, Innovation and Reform in Higher Education. Lifelong Learning Book Series (vol 25). Springer. https://doi.org/10.1007/978-3030-28227-1_12

Desjardins, R., \& Ioannidou, A. (2020). The political economy of adult learning systems-some institutional features that promote adult learning participation. Zeitschrift für Weiterbildungsforschung, 43, 143-168. https://doi.org/10.1007/s40955-020-00159-y

Desjardins, R., Rubenson, K., \& Milana, M. (2006). Unequal Chances to Participate in Adult Learning: International Perspectives. UNESCO.

Desjardins, R., Melo, V., \& Lee, J. (2016). Cross-national patterns of participation in adult education and policy trends in Korea, Norway and Vietnam. Prospects, 46(1), 149-170. https://doi.org/10.1007/s11125-016-9384-3

Eurostat (2016a). 2016 AES manual. Available from: https://circabc.europa.eu/sd/a/700a220d-33dc-42d4a5c4-634c8eab7b26/2016\%20AES\%20MANUAL\%20v3_02-2017.pdf

Eurostat (2016b). Classification of learning activities manual. Publications Office of the European Union.

Grotlüschen, A., Buddeberg, K., Redmer, A., Ansen, H., \& Dannath, J. (2019). Vulnerable Subgroups and Numeracy Practices: How Poverty, Debt, and Unemployment Relate to Everyday Numeracy Practices. Adult Education Quarterly, 69(4), 251-270. https://doi.org/10.1177/0741713619841132

Hamplová, D., \& Simonová, N. (2014). Adult Learning in the Czech Republic: A Youth- and Femaleoriented System? In H. P. Blossfeld, E. Kilpi-Jakonen, D. Vono de Vilhena, \& S. Buchholz (Eds.), 
Adult Learning in Modern Societies: Patterns and Consequences of Participation from a Life-course Perspective (pp. 283-304). Edward Elgar. https://doi.org/10.4337/9781783475186.00023

Hämäläinen, R., De Wever, B., Malin, A., Cincinnato, S., Prieto, L. P., Persico, D., Villagrá-Sobrino, S. L., \& Conlan, O. (2015). Education and working life: VET adults' problem-solving skills in technologyrich environments. Comunicar, 88(42), 38-47. https://doi.org/10.1016/j.compedu.2015.04.013

Iñiguez-Berrozpe T., Elboj-Saso C., Flecha A, \& Marcaletti F. (2020). Benefits of Adult Education for Low-Educated Women, Adult Education Quarterly, 70(1), 64-88. https://doi.org/10.1177/0741713619870793

ISCED (2011). International standard classification of education (ISCED) 2011. UNESCO Institute for Statistics.

Kalenda, J. (2015). The Issue of Non-formal Adult Education in the Czech Republic. Asian Social Science, 11(3), 37-48. https://doi.org/10.5539/ass.v11n3p37

Kalenda, J., \& Kočvarová, I. (2020). Participation in non-formal education in risk society. International Journal of Lifelong Education. Early Access Online. https://doi.org/10.1080/02601370.2020.1808102

Kalenda, J., \& Smékalová, L. (2015). Social Reflection of Community Education in the Czech Republic. Proceedings of the $12^{\text {th }}$ International Conference Efficiency and Responsibility in Education, 2015, 231-238.

Kalenda, J., Kočvarová, I., \& Vaculíková, J. (2020). Determinants of Participation in Nonformal Education in the Czech Republic. Adult Education Quarterly, 70(2), 99-118. https://doi.org/10.1177/0741713619878391

Kearns, P. (2015). Organizational Learning and Development. From an Evidence Base. Routledge. https://doi.org/10.4324/9781315777320

Lancaster, A. (2020). Driving Performance Through Learning. Develop employees through effective workplace learning. Kogan Page Limited.

Lee, J. (2017). Inequality in Participation in Adult Learning and Education (ALE): Effects of Micro-and Macro- Level Factors Through a Comparative Study. University of California Press. https://doi.org/10.7312/columbia/9780231179744.001.0001

Lee, J., \& Desjardins, R. (2019). Inequality in adult learning and education participation: the effects of social origins and social inequality. International Journal of Lifelong Education, 38(3), 339-359. https://doi.org/10.1080/02601370.2019.1618402

Messmann, G., Segers, M., \& Doochy, F. (Eds). (2018). Informal Learning at Work. Triggers, Antecedents and Consequences. Routledge. https://doi.org/10.4324/9781315441962

Merriam, S. B., \& Baumgartner, L. M. (2020). Learning in Adulthood. A Comprehensive Guide. John Wiley $\&$ Sons.

Milana, M., Holford, J., \& Mohorčič Špolar, V. A. (2016). Introduction - Adult and lifelong education: global, national and local perspective. In M. Milana, M. J. Holford, \& V. A. Mohorčič Špolar (Eds.), Adult and Lifelong Education. Global, national and local perspectives (pp. 1-9). Routledge. https://doi.org/10.4324/9781315627366

Nygren, H., Nissinen, K., Hämäläinen, R., \& Wever, B. (2019). Lifelong Learning: Formal, non-formal and informal learning in the context of the use of problem-solving skills in technology rich environments. British Journal of Educational Technology, 50(4), 1759-1770. https://doi.org/10.1111/bjet.12807

Rubenson, K. (2018). Conceptualising Participation in Adult Learning and Education. Equity Issues. In M. Milana et al. (Eds), The Palgrave International Handbook on Adult and Lifelong Education and Learning (pp 337-357). Palgrave. https://doi.org/10.1057/978-1-137-55783-4_18

UNESCO (2020). Embracing a culture of lifelong learning. Contribution to the Futures of Education initiative. UNESCO Insititute for Lifelong Learning.

Vaculíková, J., Kalenda, J., \& Kočvarová, I. (2020). Hidden gender differences in formal and non-formal adult education. Studies in Continuing Education. Early Access. https://doi.org/10.1080/0158037X.2020.1732334 